The Antwerpian Printer Jacob van Liesvelt, his Widow and their Bibles. Myths and Facts from a Confessional Era.

\title{
WIM FRANÇOIS
}

The unfortunate story of Jacob van Liesvelt, the Antwerpian printer beheaded in 1545 because he had dared to publish books without the prior consent of the competent authorities, has been told and retold many times. In an early Protestant tradition, it was argued that Van Liesvelt died because of certain Reformation-minded marginal notes contained in the Bible of 1542, an argument that has been continuously elaborated upon over the years, giving rise to the myth of Van Liesvelt as the martyr of the Word of God. This article critically questions the story of Van Liesvelt's execution, showing ways to 'debunk' the myth. However, in her book Pragmatic Toleration (2015), the American scholar Victoria Christman reworks a theory earlier put forward in an article in The Sixteenth Century Journal (2011), building on the Van Liesvelt myth from husband to widow. She argues that the latter, Maria Ancxt, simply continued her husband's Protestant Bible production, uninhibited by his terrifying fate and without experiencing any form of judicial censure. This essay, in contrast, presents a painstaking study of Ancxt's entire Bible production, which firmly arrives at the conclusion that it was largely Catholic in character-although Ancxt explored the boundaries of what was possible - and that this is the reason why she was never disturbed by the authorities. This essay therefore also includes more general remarks on confessionally or ideologicallycolored history writing - in the past and present - as well exploring its boundaries. 
The unfortunate story of Jacob van Liesvelt, the Antwerpian printer born in 1489 and beheaded in 1545 because he had dared to publish books without the prior consent of the competent authorities, has been told and retold many times. In an early Protestant tradition, it was even emphasized that Van Liesvelt died because of certain Reformation-minded marginal notes contained in his famous 1542 Bible. This tradition has proven to be very persistent over the centuries, although there are grounds to treat it with some critical distance. Moreover, other elements have been added to the mix, so that a genuine "myth" about Van Liesvelt and his Bible production has been created over time, a process quite characteristic of the “confessionalisation" process. In this article I will critically retell the story of Van Liesvelt's execution, showing ways to "debunk" the myth. ${ }^{1}$ But there is more, the confessionalized story of Van Liesvelt found a sequel in the book Pragmatic Toleration... that the American scholar Victoria Christman published in 2015, where she reworks a theory earlier put forward in an article in The Sixteenth Century Journal (2011). It is argued that Van Liesvelt's widow, Maria Ancxt simply continued her husband's Protestant Bible production, uninhibited by his terrifying fate and without experiencing any form of judicial censure. In my essay, in contrast, I will present a painstaking study of Maria Ancxt's entire Bible production, which brings about no other conclusion than that it was largely Catholic in character-although she explored the boundaries of what was possible-and that this is the reason why she was never worried by the authorities. Christman's theory ventures to add a further element to the myth that accompanied Van Liesvelt's Bible production, and one that is now extended to his widow. I will therefore conclude by giving more general remarks on confessionally or ideologically-colored history writing and its boundaries. 


\section{JACOB VAN LIESVELT BEHEADED AS A CONSEQUENCE OF AN ANNOTATION IN HIS 1542}

\section{BIBLE: BETWEEN MYTH AND FACT}

Jacob van Liesvelt (1489-1545) was active as a printer in Antwerp from 1520 until 1544 and is renowned for not having limited himself to orthodox publications but for having brought, in addition, heterodox, Protestant, materials onto the market, in a period during which such acts were liable to severe punishments by the imperial edicts in the Low Countries. ${ }^{2}$ Most famous are his editions of the New Testament and the Bible, 19 in total, that since 1526 can be traced to the Luther Bible and that the Dutch Protestants cherish as being at the heroic beginning of their important tradition of Bible printing and Bible reading. These editions have been subject to elaborate research, thus we will not enter into detailed analysis on them. ${ }^{3}$ In the context of our contribution, it is, however, not insignificant that Van Liesvelt adapted some of the confessionally sensitive passages in his complete Bible-editions (not in his New Testament editions) to the Vulgate text:

Matthew 3:2 |1532 Jacob van Liesvelt: "Betert U” ("Mend thy ways") | 1538 Hansken (I) van Liesvelt: "Betert U"

Matthew 4,17 | 1532 JvL: "Betert U”| 1538 HvL: "Doet penitencie" ("Do penance”vulgatized)

Matthew 16:18 | 1532 JvL: "ghi sijt Petrus ende op desen steen sal ic timmeren mijn gemeynte" ("Thou art Peter, and upon this rock I will build my congregation") | 1538 HvL: "ghi zijt Petrus ende op desen steen sal ick tymmeren mijne kercke” (“Church”—vulgatized)

Romans 3:28 | $1532 \mathrm{JvL:} \mathrm{"So} \mathrm{houden} \mathrm{wi} \mathrm{nu} \mathrm{dat} \mathrm{die} \mathrm{mensche} \mathrm{gerechtvaerdicht} \mathrm{wort} \mathrm{sonder}$ toedoen die wercken des wets alleen door tghelove" ("Therefore we hold that a man is justified without the works of the law, by faith alone") | 1538 HvL: "So houden wi nu dat die 
mensce gherechtverdicht wordet door dat gheloove sonder die wercken des wets" (without insertion of the lutheran "alone")

James 5:14 | 1532 JvL: "Isser yemant cranc onder u die hale die oudtste vander ghemeynten" ("Is any man sick among you? Let him bring in the elders of the congregation") | 1538 HvL: "Isser yemant cranc onder u die hale die oudtste vander vergaderingen" (“assembly").

These "vulgatizations," as well as the recourse to the pseudonym of "Hansken" (this may be the name of an actual relative), might be in response to the problems Liesvelt had experienced for having published forbidden books in general and Bibles in particular. Specific reference should be made to the annual accounts of the margrave from 1535-1536 showing that the executioner of the town of Antwerp had received compensation of twenty-two sixpences ("schellingen") and six deniers (“deniers") for having publicly burned Bibles and other books from Van Liesvelt's workshop. ${ }^{4}$ This is one of the rare pieces of evidence we have of genuine burnings of copies of the Bible in the Low Countries. Also, on other occasions Van Liesvelt ran into troubles as a result of having published "forbidden books."

Notwithstanding the "vulgatization" of some of the confessionally sensitive passages in the complete Bibles since 1538 (albeit not in the separate New Testament editions), Van Liesvelt did not shy away from including, with every new edition, an increasing amount of paratextual elements having a more outspoken Reformation-minded character. The apogee of Van Liesvelt's Bible publications was his 1542 Bible, using the vulgatized text from 1538, but including a register and marginal glosses—next to other paratextual elements_-bulging with Reformation-minded statements.

In May 1545, Van Liesvelt was arrested once again and eventually brought before the local tribunal (Vierschaar). ${ }^{6}$ The arrest took place less than half a year after the imperial edict of 
December 18, 1544 had been released, which, as an update to the major anti-heresy legislation of 1540, listed all the points concerning preventive and repressive book censorship, toughening them where necessary. ${ }^{7}$ The Antwerp sheriff had initiated this new prosecution of Van Liesvelt, because the latter was said to have again printed several books evidently without having gained the required permissions. At that particular phase in the (religious) history of the Low Countries, continuous non-compliance with book regulations was considered to be irrefutable proof of heterodoxy; the fight against heresy was largely a fight against forbidden religious books, which can be seen in the elaborate regulations regarding the printing press, contained in the anti-heresy edicts. In light of the later account of the events, it is important to stress that the accusation against Van Liesvelt, as it is recorded in the archival documents relating to the 1545 trial, contains no specific reference to any of his contested books, let alone to one of his Bible editions. In his defence, which the Antwerpian printer prepared with the assistance of two lawyers, Van Liesvelt also did not refer to the publication of any prohibited Bibles, which raises the question as to whether an accusation of this kind could have played a major role in the trial. Moreover, Van Liesvelt used the same defence as he had done during another trial three years earlier. He declared that the books contested by the sheriff had been printed by various printers long before the edicts were issued. Since these books had not been forbidden by any official regulation, and some even had been printed "cum gratia et privilegio," Van Liesvelt had assumed that he could reprint them without any repercussions. Moreover, Van Liesvelt stated that he had reprinted these books before the date of the last edict. In any case, he argued his behaviour had been bona fide. In light of all these reasons, Van Liesvelt was of the opinion that there was nothing with which he could be charged. ${ }^{8}$ The verdict of the trial was continuously adjourned, with different reasons being evoked for this each time. At first the aldermen-judges had not been in sufficient number, then the burgomaster had been absent... in the final phase of the trial, Van 
Liesvelt was ill, meaning that on several occasions he was not able to appear before the judges. This gives the impression that the judges in Antwerp kept postponing the trial, and that there was not much inclination to deal with the printer harshly, which may have been detrimental to the economically important printing industry. This situation continued until the end of November 1545. All at once, the case was hastily accelerated, which the Antwerp town archivist Floris Prims attributed to the intervention of the Brussels Attorney General, who may have overruled the Antwerp jurisdiction over the case-a hypothesis that Prims does not substantiate with references to any archival materials, but that is not unreasonable to deduce. ${ }^{9}$ In any event, Jacob van Liesvelt was sentenced to death on November $27,1545^{10}$ and was beheaded the next day. In the books from the local tribunal, the margin of the page contains the notorious words: "executio facta."11

Again, Van Liesvelt was not executed for failing to observe a mere administrative requirement, viz. not asking for the necessary permissions prior to the publication of (some of) his books. The reason for his execution was his (repeated) non-compliance with book censorship measures contained in the anti-heresy edicts, which, as we have seen, was considered irrefutable proof of being involved in spreading forbidden heterodox literature. By the 1540 s, the central government was determined to show its commitment to the issue, by implementing a repressive policy which effectively persecuted printers such as Van Liesvelt, who did not shy away from publishing all kinds of heterodox books (not merely Bibles). As a consequence of this increased repression, Protestants started to leave the Low Countries, mainly to London; but after the accession to the throne of the Catholic Queen Mary in 1553, they sought refuge in the East-Friesian town of Emden, as well as Wesel, Frankenthal and other German territories. The Protestants took with them, in the Diaspora, the Liesvelt Bible and used it as a basis for further editions and revisions, especially in Emden at the end of the 1550s and in the 1560s. The Liesvelt Bible was held in great esteem by these refugees, and 
received a quasi-mythical status since it was linked to the heroic and difficult beginnings of Dutch Protestantism. ${ }^{12}$

Of interest to our topic is that, two decades after Van Liesvelt's execution, a connection was made between his being sentenced to death and the Reformed-minded Bibles that had been produced by his printing office. Crucial is this regard was the booklet De beschriivinge van den gheschiedenissen in der religien saken toeghedragen in den Nederlanden [Description of the History in the Matter of Religion as Happened in the Netherlands], written by Jacob van Wesenbeke and published in 1569. For in this work a short note is included, according to which Van Liesvelt was accused before the tribunal as a result of a marginal note in a Bible, which read that "man's salvation was brought about by Christ alone."13 The short passage does not contain a reference to the 1542 Bible, nor to any other concrete edition. Most striking however is the contrast between Van Wesenbeke's note and the records of the 1545 trial in the Antwerp Archives, which include no reference at all to Van Liesvelt's Bible, let alone to any of its explicit Reformation-minded marginal notes (but only contain the general charge of having printed several books evidently without having gained the required permissions). Therefore, the central question is whether Van Wesenbeke's note gives us additional factual information with regard to the trial, or whether it represents the birth of a myth that would surround the Antwerpian printer in the decades and even centuries after his execution. An assessment of the role of Van Wesenbeke in the history of the Dutch Revolt in the midsixteenth century should be taken into consideration in order to answer this question.

Jacob van Wesenbeke $(1523-1575)^{14}$ trained as a jurist and became Antwerp's town secretary in May 1546, succeeding his father, who was in office at the time of Van Liesvelt's trial, and who may for that reason be considered a first-hand witness. ${ }^{15}$ In 1556 Van Wesenbeke was appointed pensionary of the town, and, in this way, the most important legal officer in the 
town. In the famous Wonder Year 1566, when William of Orange was appointed Governor of Antwerp with the aim of restoring peace in the city after the iconoclastic riots, Jacob van Wesenbeke—who was himself a member of the Lutheran community—was asked to act as a mediator between the Magistrate, the different politico-religious factions of the town, and the Governor. ${ }^{16}$ In April 1567 however, at the eve of the restoration of the King's authority over the city, William of Orange sent Van Wesenbeke ahead to Dillenburg, not only with an eye to his collaborator's safety, but also because the latter had at his disposal much insideinformation that needed, at all cost, to be kept out of the adversary's hands. In May 1568, the Council of Troubles, installed by the Duke of Alba, sentenced Van Wesenbeke by default to banishment and ordered forfeiture of his goods. In Dillenburg meanwhile, Van Wesenbeke turned out to be the ghost-writer and first propagandist of William of Orange and his movement, and he was officially appointed the Prince's counsellor. ${ }^{17}$ In several apologetic works and pamphlets, published mainly around the years 1568-1569, it was emphasised that the government's edicts against heresy violated the privileges and liberties of the Low Countries and, consequently, threatened the country's economic prosperity. For these reasons, so the pamphlets stressed, the Prince of Orange had rightly taken the lead in the revolt against the Spanish King, and all his compatriots ought to join the movement with the aim of liberating their country. ${ }^{18}$

It was in August 1569 that Van Wesenbeke published the aforementioned Description of the History in the Matter of Religion as Happened in the Netherlands. Van Wesenbeke had possibly already finished the book in the Wonder Year 1566, and had written the work, according to a note of his, at the request of the higher authorities, which likely meant the Prince of Orange himself. ${ }^{19}$ The book, however, could not be published immediately, due to a lack of means, which the Prince possibly resolved ${ }^{20}$ In addition to the Dutch text, a French version of the edition was published. ${ }^{21}$ Poignant to note however, is that the work is said to be 
founded on a large number of records and letters, which Van Wesenbeke would have taken with him when he left Antwerp (next to the seals of the town). ${ }^{22}$ Van Wesenbeke's work for the Prince of Orange was not only limited to publication activities, he also travelled around in order to help establish the coalition against the Duke of Alba, to hatch plots, and collect money for the Revolt. ${ }^{23}$

We now return to the short note included in Van Wesenbeke's Description of the History in the Matter of Religion as Happened in the Netherlands, according to which Van Liesvelt was accused before the tribunal as a result of a marginal annotation in a (Dutch) Bible reading that “man's salvation was brought about by Christ alone." Notwithstanding the fact that the Bible of 1542 is stuffed with marginal glosses, an annotation which literally contains the words in question, is not to be found. The content of Van Wesenbeke's note, however, is more or less represented by a gloss to Colossians 1:3: "Grace that is forgiveness of sins by Christ, peace that is the internal assurance that we believe for sure to be saved by Christ." ${ }^{24}$ In a gloss to Matt. 4:22 we read: "Gospel, that is the proclamation of the grace and salvation received and given by Christ, which has been long waited for." ${ }^{25}$ Also to be considered is the summary of Rom. 10, which includes the words: "the justice that makes [man] worthy of eternal life, is solely to be found in the law and the Faith of Jesus Christ"; ${ }^{26}$ to this should be added the reference to the passage in question, included in the register to the New Testament in the preliminary pages of the Bible, which reads: "The grace of Jesus Christ is our salvation, and not the works."27

The fact, however, that none of the biblical glosses contain the exact words quoted by Van Wesenbeke must be considered together with the aforementioned finding that the archival records of the Van Liesvelt trial do not make mention of any of Van Liesvelt's Bibles, let alone of the Reformation-minded glosses it includes. And although Van Wesenbeke may have 
had first-hand information on Van Liesvelt's execution at his disposal, and was to become Antwerp's town secretary shortly thereafter-making him one of the best informed people in the town-he was also a clever propagandist in the service of the Prince of Orange, in the period between the latter's first and second campaign in the Low Countries. In the confessional era, history writing was considered as an important polemical tool to advance the cause of the Reformation. For these reasons, it must be critically assessed whether a gloss of the kind cited by Van Wesenbeke, was actually an element of consideration in the 1545 trial, or whether Van Wesenbeke's note marked the beginning of the creation of a myth representing Van Liesvelt as a martyr of God's Word.

\section{JACOB VAN LIESVELT AND HIS 1542 BIBLE: A MYTH SPREADS}

Whatever the case may be, Van Wesenbeke's note was picked up from the beginning by the Dutch Protestants and included in the story or myth that was built up, piece by piece, about Van Liesvelt. The construction of such narratives or myths typically belongs to the sixteenth century "confessionalisation process," whereby the various confessions or denominations built up their own identity, and often did so in confrontation with or in denigration of the "other." Whereas some elements already belonged at an early stage to the story, others were later added, some of them even in the nineteenth century, when a "second confessionalisation process" took place, generally situated between the 1850s and the 1970s, and opposing not only Protestants (of several denominations) and Catholics, but also liberals, socialists and other ideological groups. Accordingly, I will give the elements that were added to the Van Liesvelt story or myth a number from one (1) to five (5). Already in Boek-Zaal der Nederduytsche Bybels [The Library of Dutch Bibles] published by Isaac le Long in $1732,{ }^{28}$ we find three elements of this scenario playing out: (1) The immense popularity of the Liesvelt- 
Bible, which Le Long emphasized was reprinted several times and was read and honored by the Dutch Protestants (of different denominations). It was the privileged Dutch edition "until a few years before the New Reformed Translation was made."29 (2) Van Liesvelt had been beheaded "during the most severe persecution of the supporters of God's Word," and this because of the famous marginal annotation in one of his Bibles, as was recorded by "Sir Jacob van Wesenbeek, Counselor and Pensionary of the town of Antwerp who himself witnessed it"; ${ }^{30}$ (3) The Protestants' self-identification as partisans of God's Word was further confirmed through the process of contrasting themselves with their Catholic opponents. The latter were depicted as grim opponents of vernacular Bible reading, and have therefore prohibited Van Liesvelt's Bible (as well as other publications) and put them on the Index. Le Long refers, furthermore, to Nicholas van Winghe, who issued a Catholic Bible translation on the basis of the Vulgate in 1548, and adduced as a reason for the prohibition of other Bibles such as those of Van Liesvelt that "the false Bibles should be neutralized, and not that it should be prohibited necessarily to read the Holy Scriptures in the vernacular." However, Isaac le Long corrects Van Winghe, saying that it was not the Reformation-minded but the Roman Catholics who had falsified the Bible. ${ }^{31}$

A milestone in the creation of the myth regarding Jacob van Liesvelt was the work Schetsen uit de lijdensgeschiedenis der Protestantsche Apostolisch-Katholieke Kerk [Sketches from the History of the Persecutions of the Protestant Apostolic-Catholic Church] published by Albert van Toorenenbergen in $1854 .{ }^{32}$ As is suggested by the title, this work trod the middle ground between a martyrology in the strict sense of the word, and a (polemical) history of Protestantism. The book fitted in with the campaign organized by the Dutch Protestants against the restoration of the Catholic hierarchy in the Netherlands in 1853, and therefore assumed a bitterly anti-Catholic tone. In his paragraph on Van Liesvelt, Van Toorenenbergen noticed that " $[\mathrm{t}]$ he last edition, from 1542, had hardly been completed, an edition in which 
Liesveldt had added various marginal annotations ... but, especially, the clergy had hardly read that 'man's salvation was brought about by Christ alone', and the fate of publisher was decided." ${ }^{, 33}$ In the notice, no explicit mention was made about Van Wesenbeke. More important, however, was that Van Toorenenbergen added to the established portrayal of Van Liesvelt (4) some quite explicit references concerning his status as a martyr for spreading the true Word of God. Van Toorenenbergen obviously wanted to compensate for the fact that the Bible publisher had never been included in the official martyrologies of the Reformed Church in the Netherlands, underscoring the fact that he "has sacrificed everything for the Bible," had "died for the Bible, which he had revised himself, printed, published, and bloodily sealed."34

But also in the South, in Belgium, a "pillarization" took place in nineteenth century society, one that pitted anti-clerical "free-thinking" liberals against Catholics. Over the course of eight-volumes Geschiedenis van Antwerpen [History of Antwerp] (1845-1853), the liberal historians Frans Hendrik Mertens and Karel Lodewijk Torfs give Jacob van Liesvelt a place within their ideological framework. With regards to possible causes of Van Liesvelt's execution, they do not only refer to the famous annotation recorded by Van Wesenbeke, but also to a (5) new and surprising element, viz. the image printed for Matthew 4:3, depicting the devil who tempts Jesus in the desert and who has the shape of a bearded monk, with frock and cap and a rosary hanging from his belt. Under the habit, the goat's paws are still visible, and the horns still stick out above the cap. Mertens and Torfs suggest that this anticlerical image "was considered as an unforgivable villainy," giving credence to their conviction that this insult towards the Catholic clergy must have played a role—even a crucial one-in Van Liesvelt's ultimate condemnation, ${ }^{35}$ although this viewpoint is not supported by the sources at all. Earlier in this passage on the history of Antwerp, Mertens and Torfs had already praised Van Liesvelt and other printers-who had refused to exercise their profession within the Saint-Lucas guild—for having "defended the freedom of the printing press, which some 
aimed, already by then, to curb." ${ }^{36}$ In other words, the nineteenth century liberal Antwerp historians Mertens and Torfs depict Van Liesvelt as a hero for the liberal freedom of the printing press, who was eventually condemned and executed by the Catholic clergy and their allies, who, in their turn, were blinded by dogmatism and fanaticism and unable to tolerate any critical voices.

The suggestion that the anticlerical image inserted in the gospel story about the temptations in the desert (Matthew 4:3), may have played a role in Van Liesvelt's condemnation did, in turn, find its way to the North, where it was grist to the mill for Protestant polemists. Hendrik van Druten, in his still valuable Geschiedenis der Nederlandsche Bijbelvertaling [History of the Dutch Bible Translation] (1895-1905), ${ }^{37}$ was quite prudent when he referred to the relevance of the woodcuts, and withheld from stating explicitly that they had played a role in the condemnation of Van Liesvelt. ${ }^{38}$ In addition, Van Druten included elements of Van Liesvelt's established reputation. Remarkably, the author stressed only in general terms that it was not so much because of his text, but particularly because of his notes, that Van Liesvelt's 1542 edition had been outlawed and the printer himself been found guilty and sentenced to death. The author, thus, does not mention specifically the famous gloss quoted by Van Wesenbeke, which the scholar was evidently not able to find in the 1542 edition. ${ }^{39}$ A somewhat popularizing and polemic Protestant booklet was De herkomst van den Bijbel [The Origin of the Bible] (1925) by Jan Frederik Beerens. ${ }^{40}$ The section about the Dutch Bible translations was in content inspired by the works of Hendrik van Druten, but the discourse had been sharpened in a polemical Protestant fashion. Apart from the clear reference to the annotations in the 1542 Bible, the author also suggests that Van Liesvelt's woodcuts, which were very "provoking," may have played a role in the condemnation of Van Liesvelt in 1545 to "death by fire" (sic!). And he concludes: "Precisely therefore his edition was held in high esteem among the Protestants. For it was consecrated by martyrs' blood."41 
Another viewpoint was clearly defended by the aforementioned Floris Prims, the Catholic priest, historian and archivist of the town of Antwerp, active from 1925 until his retirement in 1948. Prims had become very renowned because of his 29 -volume history of the town of Antwerp, which he published between 1927 and 1949. In volume 7, which was devoted to Antwerp under the first Habsburg, Prims gives an account of the trial and execution of Van Liesvelt, as best he could reconstruct from the archival materials, with which he was very familiar. ${ }^{42}$ He writes that Van Liesvelt was sentenced because he had dared to publish books without the prior consent of the competent authorities, whilst also emphasizing that it was certainly not exclusively nor in particular because of his 1542 Bible, "as can be read everywhere." 43 And as a conclusion to his passage on Van Liesvelt, he gibes at Jacob van Wesenbeke "who wrote that Van Liesvelt was condemned because of a marginal note that 'man's salvation was brought about by Christ alone'." Prims continues that "this is a tendentious and very incomplete representation," since he doubts that this element might have played a major role—if any role at all—in the trial. ${ }^{44}$ In this sense, Prims distances himself from the authors who had believed and reproduced Van Wesenbeke's representation, not only those Northern Dutch Protestant writers but also his Belgian liberal fellow historians from the past century.

But also in the North, spirits grew more prepared to accept a historical assessment of the events that led to Van Liesvelt's execution. A milestone, as well as a turning point, in this regard was the publication of De Statenbijbel en zijn voorgangers [The Dutch Standard Version and its Predecessors] by Cornelis Cebus de Bruin in $1937 .{ }^{45}$ De Bruin has undertaken valuable attempts to offer an objective, scholarly overview of the Dutch Bible translations, although the author's Protestant background still influenced the language and the perspective of this work. (1) De Bruin waxes lyrical about the important role the Liesvelt Bible played in the Protestant refugee churches in London and Emden. Of course, he also mentions the 
numerous reprints of the Bible, which he self-evidently attributes to the Bible's popularity among the Protestant population. ${ }^{46}$ The tradition in which De Bruin stands, also leads him to accept without critical questioning, the view that (2) the sheriff of Antwerp had prosecuted Van Liesvelt because the marginal notes in his last Bible [meaning the edition of 1542] include that "man's salvation was brought about by Christ alone"; without referring to Jacob van Wesenbeke as a source, he simply states that the "official administrative pieces" prove this to be the case. ${ }^{47}$ De Bruin, however, seriously criticized the viewpoint that the woodcuts accompanying Matthew 4:3 may have played a role in the case against Van Liesvelt, invoking several arguments. He pointed to the simple fact that the archives do not mention a single word about the woodcuts. Besides this, the image in question also appears in other Bibles that were not targeted by the authorities. De Bruin points out that the Catholic Church always tolerated some critique of its authority to a certain extent, as long as the right doctrine remained untouched. The designer of the woodcut also possibly wanted to demonstrate that the devil can wrap himself up even in the habit of an innocent monk, and in this way pass himself off as a wolf in sheep's clothing. ${ }^{48}$ Moreover, De Bruin praises the Catholic translation of the Vulgate by Nicholas van Winghe (1548). ${ }^{49} \mathrm{He}$ also explicitly puts forward that there were actually some reasons to doubt Van Liesvelt's martyr status. ${ }^{50}$ The arguments of De Bruin are the following: the printer-editor had continued to print Catholic works; during the trials, printers such as Van Liesvelt never conducted themselves as fearless supporters of the Protestant faith, but instead invoked excuses in order to avert a sentence. And furthermore, as a professional printer, Van Liesvelt aimed at financial gain, thus argues De Bruin, while the author at the same time emphasizes that he must have felt some sympathy for the new doctrine, otherwise he would not have taken such major risks. ${ }^{51}$ In this spirit, De Bruin concludes his paragraph about Van Liesvelt: "In this way we remember with respect the brave 
Antwerp editor, who with his Bibles has been a blessing for innumerable persons without caring for his own life." 52

Despite Floris Prims's doubts whether the Reformation-minded gloss that "man's salvation was brought about by Christ alone" presumed to be in Van Liesvelt's [1542] Bible may have played a major role in the printer's condemnation, and despite the more scholarly approach adopted by De Bruin, the influential Dutch bibliographer Maria Elizabeth Kronenberg stuck, astonishingly, to a very confessional-Protestant approach in her work Verboden boeken en opstandige drukkers in de Hervormingstijd [Forbidden Books and Rebellious Printers in the Time of The Reformation], which was published in $1948 .{ }^{53}$ In this book, she proclaims in a general way that "the printing of the so-called Liesvelt Bible of 1542, which remained highly respected by the Protestants, was the immediate cause for the printer's death sentence. ${ }^{, 54}$ In a militant tone, she exclaims the following statement regarding printers such as Van Liesvelt: “One looks in vain for all their names in Van Haemstede's work on the Dutch martyrs. They did actually deserve to be recorded in it." ${ }^{, 55}$

Cebus Cornelis de Bruin's ground-breaking overview of the Bible translations in the Low Countries had been revised and updated by Frits G.M. Broeyer, and published in $1993 .{ }^{56}$ Only a few years later, in 1997, A.A. (August) den Hollander published his much-lauded book Nederlandse Bijbelvertalingen 1522-1545 [Dutch Translations of the Bible 1522-1545]. Den Hollander especially took a bibliographical approach and aimed "to establish the text tradition of the Dutch Bible translations published between 1522 and $1545, " 57$ without neglecting the ecclesiastical historical side of the Bible production. More specifically, Den Hollander shows reluctance in evoking the traditional portrayal of Jacob van Liesvelt and his Bible editions. ${ }^{58}$ He avoids the theory that the marginal gloss(es) in the Bible of 1542 were the cause of Van Liesvelt's arrest and death sentence, but he rightly stresses that the printer-editor was 
apprehended in 1545 due to the printing of books without having requested the necessary permission. ${ }^{59}$ Den Hollander also authored the chapter on Van Liesvelt's Bible in the new standard work on Bible translation in the Low Countries, De Bijbel in de Lage Landen: Elf eeuwen van vertalen [The Bible in the Low Countries: Eleven Centuries of Translation] (2015), summarizing the insights of the research regarding Van Liesvelt's Bible. ${ }^{60}$

With Den Hollander's approach we return to where we started this overview: the archives of the Antwerp local tribunal. They provide us indeed with the firsthand information about Van Liesvelt's trial, viz. that he was sentenced because he had, once again, printed books without having requested the necessary permission. The crucial question is of course, which significance one is prepared to attribute to Jacob Van Wesenbeke's note indicating that Van Liesvelt's [1542] Bible and its Reformation-minded glosses, even more specifically "that man's salvation was brought about by Christ alone," played a role in his condemnation. Should the note be considered as a trustworthy and faithful report of the historical facts, or conversely, as the onset of the creation of a myth that would dominate the portrayal of the printer-publisher for decades and centuries to come? It is not absurd to maintain that the option to take either the first or the second stance would be inspired by the confessional or ideological adherence of the scholar doing the research.

\section{MARIA ANCXT, WidOW OF VAN LIESVELT, AND THE OPTION FOR A CATHOLIC BIBLE FUND}

In the second part of this essay, I will take as a point of departure a passage in the book Pragmatic Toleration: The Politics of Religious Heterodoxy in Early Reformation Antwerp, 
1515-1555 published by Victoria Christman in $2015,{ }^{61}$ and which retraces a position the American scholar has already defended in an article published in The Sixteenth Century Journal in $2011 .^{62}$ Both publications directly continue the above-mentioned older historiographical tradition and the Van Liesvelt myth developed from there, by adding a new and important element (unfoundedly, as I will argue). For Christman claims that Van Liesvelt's widow, Maria Ancxt, ${ }^{63}$ in parallel to four other widows discussed in the text, continued to print heterodox Bibles after the execution of her husband in a period in which imperial and papal legislation was growing increasingly stringent towards such "crimes," but that she nevertheless escaped any form of judicial censure. In reply to this position, it should first be confirmed that in the wake of the imperial edict of 1540 , and especially the recapitulative edict of 1544 , control of the printing industry did increase in intensity, and repression tightened its grip_-and it was precisely this that had led to the sentencing and execution of Maria Ancxt's husband Jacob van Liesvelt. It should be emphasized, however, that vernacular Bibles themselves were never forbidden by the imperial decrees in question, something that even the abovementioned eighteenth century author Isaac Le Long had to admit. What were forbidden, as had been the case since the early 1520 s, were Bible editions that were provided with registers, marginal glosses, summaries above the chapters and any other paratextual elements that could steer a reader's interpretation in a heterodox direction. It comes as no surprise that also Dutch Bibles based upon the German Luther Bible were increasingly viewed with suspicion, so that editions displaying the said characteristics were eventually included in the Louvain Index of 1546. But astonishingly none of the Bibles or New Testaments printed by Jacob van Liesvelt prior to 1542 are listed in the Index, nor is mention made of the edition published under the name of Hansken (I) van Liesvelt in 1538elements that have not been sufficiently taken into consideration in the main analyses of the Louvain Index until now. ${ }^{64}$ Whatever the reason may be, within a few weeks after the 
publication of the Index, the imperial authorities, the Louvain theologians and the printerpublisher Bartholomew van Grave took the initiative to publish a "trustworthy" Dutch and French Vulgate translation, devoid of all marginal glosses, which was intended to replace all former biblical editions. The Dutch so-called "Louvain Bible" was published in 1548, and its French sister-edition followed suit in 1550 , with dozens of reprints in the next quarter of the century, especially of the New Testament part. ${ }^{65}$ Surprisingly, Victoria Christman also argues that Maria Ancxt continued to publish heterodox Bibles in open defiance not only of the imperial decrees but also of the first papal Index of $1559 .{ }^{66}$ In the Index we read that, among other stipulations, no edition of the Bible in the vernacular, nor any edition of the New Testament, should, in whatsoever way, be printed, purchased, read or held in possession, without the written permission of the Holy Office of the Roman Inquisition. In reply to this argument, we should point to the historical fact that this first Roman Index was so excessively restrictive that it received no application at all in the Catholic Church beyond the Papal States (let alone having been in force in the Low Countries). ${ }^{67}$

My point is that Maria Ancxt was indeed not subjected to any form of judicial censure, because of the simple fact that she was one of the Antwerpian printers providing Catholic or at least "catholicized" translations, although she explored the limits of what was permissible within the contours of the censorship edicts. All of Ancxt's Bible editions bore an official approbation by the competent book censor on either the title page or the colophon (or both). I came to this conclusion after the study of almost twenty editions, ${ }^{68}$ all published in Antwerp and now preserved in libraries across Europe (and beyond), but which are also increasingly available in digitized form.

Ancxt's publication activity started with two vernacular translations, in 1547 and 1548 respectively, of the Evangelien ende Epistelen..., the Epistle and Gospel readings of mass, a 
kind of book that was very popular from the late Middle Ages onwards and that enabled the faithful to follow the lessons that were read or sung in Latin at mass. ${ }^{69}$ Even the most strident adversaries of Bible reading in the vernacular were prepared to allow the laity to read such books, and its publication was therefore considered as "safe." Surprisingly, Maria Ancxt used the text of the Bible editions her husband had published (and that are said to have caused him so much trouble) as a basis. But as we remarked above, some confessionally delicate passages were "vulgatized" or "catholicized" from the Bible edition by Hansken (I) van Liesvelt onwards (and the passages with which this was not the case, as for example with James 5:14, were not used as readings in the mass). An example of this "vulgatization" is to be found in Matthew 16:13-19, the pericope that was read at the feast of the Chair of Saint Peter ("sinte Peeters verheffinge dach," February 22) as well as the feast of Saints Peter and Paul (June 29). In this pericope, we find the sentence: "Thou art Peter; and upon this rock I will build my Church,"70 where Protestant Bible editions read instead "my congregation." Moreover, books containing the Epistle and Gospel readings - as was also the case with Ancxt's editionswere preceded by a saints' calendar, traditionally printed in red and black ink. And although such calendars did not disappear immediately from Reformation-minded Bibles, by the end of the 1540s, they had become a mainly Catholic feature. The corpus containing the Epistle and Gospel readings was followed by a table of contents, which lists all the Sundays and feast days, and for each day indicates the respective page where the readings are to be found. In short, on the basis of a heterodox Bible, a thoroughly Catholic edition was composed. It comes as no surprise then that the book, after control and revision, was approved by Jaspar van Meere, the assigned book censor, as we can read in the colophon of the first edition of the work (1547). In the second edition of the work (1548), this specific mention disappeared, leaving only the words "cum gratia et privilegio" with the imperial consent to publish the edition, and mentioning that it had been inspected or "visited" by learned men. 
Aside from the Epistles and Gospels that were read in mass, the Psalms were the texts par excellence that were used in liturgy and were therefore frequently translated, copied and printed from the Middle Ages onwards. It comes as no surprise then that Maria Ancxt also brought this text onto the market. What is however very peculiar is that she used in this regard the text by Joannes Campensis, professor of Hebrew at the Louvain College of the Three Tongues (1519-1531). Campensis had made a Latin paraphrase of the Psalms on the basis of the Hebrew text, which had been published for the first time in 1532 and went through several reprints in the subsequent years. ${ }^{71}$ In 1533 , the Louvain theologians, replying to a request for advice from the governess of the Low Countries, had pronounced a negative judgment regarding the publication of a Dutch and a French translation of Campensis's Psalter. ${ }^{72}$ Notwithstanding the negative advice, several editions containing a Dutch, French or other vernacular version had been published over the course of the 1530s. Strangely enough, not a single edition had afterwards been added to the 1546 Louvain Index. ${ }^{73}$ This was obviously the reason that in 1548 Maria Ancxt took the decision to reprint the Dutch text of Den Psalter according to Campensis's version; with three print runs known to have been undertaken in the same year. ${ }^{74}$ Moreover, also in this instance, she received the explicit permission for the publication from Jan Goossens, pastor of the church of Saint Jacob in Antwerp (1552-1557) and book censor by imperial mandate. The Psalms text was followed by the Dutch version of the Letter of Saint Athanasius to Marcellinus, based upon the Latin translation Johann Reuchlin had made from the Greek original. The material regarding the Psalms was followed by a Dutch paraphrase of the book Ecclesiastes, likewise made by Campensis, as well as a contemplation on the Our Father Prayer. The booklet was introduced by a Letter from Campensis addressed to Joannes Dantiscus, who had been bishop of Culm since 1530; and was accompanied by an address to the reader from Campensis. In later editions of Campensis's Psalter, Ancxt had a saints' calendar added, immediately following the title 
page. ${ }^{75}$ In 1549 or 1550 , Maria Ancxt did publish a Dutch translation of the Wisdom books of Solomon, with the express approbation by the aforementioned Jan Goossens. And in 1551 a second edition followed.

After publishing editions of the Epistles and Gospels, as well as the text of the Psalms, Maria Ancxt ventured into the flourishing market for New Testaments, both in Dutch and French. Seven editions of the Dutch Dat gheheel nyeuwe Testament... (or variants in spelling of the same title) are known to have left her printing office between 1553 and 1565 (but possibly she published even more editions) ${ }^{76}$ All editions were provided with a "cum gratia et privilegio." They are part of the more than forty editions of the (Catholic) New Testament that are known to have been published up until the 1570s, all offering the Catholic Louvain Bible text of 1548, and all following a similar composition. ${ }^{77}$ This means that the text is preceded by a calendar of saints, and is followed by those passages from the Old Testament that were read as a lesson during mass, as well as by a register indicating which pericopes from the Bible were to be read on each Sunday and feast day and the respective pages where they were to be found. This particular format of Catholic New Testament editions during the said period made them suitable for use during the official liturgy of the Church. The text Maria Ancxt offered is completely identical to that of the officially authorized Louvain Bible (1548), as becomes apparent on the basis of a comparison of our "test text" of Matthew 16:13-19 "Ende ick segghe u dat ghi Petrus zijt, ende op desen steen sal ick tymmeren mijn kercke" (“Church”). This finding is confirmed by comparing a series of confessionally sensitive passages that all give a Catholic reading: Matthew 3:2 and Matthew 4:17, which read in the Vulgate as "Paenitentiam agite" are translated as "Doet penitentie" ("Do penance," thus not "Mend thy ways" or "Repent"); James 5:14 reads: "Isser yemandt onder u lieden sieck? die hale die Priesters der kercken" ("Is any man sick among you? Let him bring in the priests of the Church," and not "the elders of the congregation"); and as a translation of Romans 3:28 we 
read "Want wy houden voorwaer dat die mensch gherechtveerdicht wordt door tgheloove, zonder die wercken des wets" ("For we account a man to be justified by faith, without the works of the law"; the Lutheran apposition to faith "alone" was evidently removed).

Two features, however, of Maria Ancxt's Dutch New Testaments made them somewhat peculiar. First, they bear on the title page a quotation of Mark 16:15-16a: "Go ye into the whole world and preach the gospel to every creature. He that believeth and is baptized shall be saved." According to August den Hollander, the printing of this quotation on the title page of a New Testament edition induced the Louvain theologians to include such editions in the Index of 1546, since it was considered as a token of Protestant sympathy, although the theologians did not make their motif explicit. ${ }^{78}$ If this is indeed the case, then Maria Ancxt's mentioning of the Bible verse was a daring attempt to explore the limits of what was still possible. Moreover, Maria Ancxt also included summaries above the chapters of the New Testament books that were essentially borrowed from the New Testament and Bible editions that the Liesvelt house had published in the decades before, albeit these summaries were largely catholicized. Inclusion of such summaries was quite a new element, since they were absent from the format of the Louvain Bible of 1548, and they would only be added to the revised version of the Louvain Bible in 1553. The publication of the 1553 Louvain Bible came too late for Ancxt, so she opted for a "catholicized" version of the summaries her late husband had used in his editions. The summary above Matthew 16 according to the Liesvelt New Testament included the words "How Jesus said that He would build his Church on the confession of the faith." Since the addition of "on the confession of the faith" and thus the concealment of Peter's ministry was considered an expression of Reformation-minded insights, ${ }^{79}$ Ancxt had it removed from her editions of the New Testament. The catholicization of the summary was completed by the addition of the sentence "God will reward everybody on the basis of his works"- the emphasis on the works as a (co-)source of salvation being a 
genuine Catholic stance. ${ }^{80}$ Also, in her later editions of the New Testament, Ancxt retained these summaries, which resulted in the summary above Matthew 16 sounding even more Catholic than the summary included in the 1553 Louvain Bible, which has quite a neutral tone $!^{81}$

In 1560 Marie Ancxt printed two editions of the complete Bible for Jacomyne Bars, the widow of Henrick Peetersen van Middelburch. The text (and its summaries) were the same as the 1553 Louvain Bible, and it was preceded by a (shortened) prologue by the translator Nicolaus van Winghe, as was also contained in the same edition of 1553. Ancxt's Bibles, as was the case with all her biblical editions, displayed the "cum gratia et privilegio" wording on the title page, whereas at its verso side the following is printed: "the Bible was checked and approved by learned men who had received a mandate to that aim by the Emperor," and that it was therefore "admitted to be printed." 82 A more Catholic format than that was not to be found on the market at the time... More rare is the edition that Maria Ancxt printed for another Antwerp printer, Symon Cock (in the same year 1560) with the same format as the edition printed for Jacomyne Bars. ${ }^{83}$

Maria Ancxt also ventured into the market for French New Testaments. In 1553, in the same year she published a Dutch New Testament, she also brought a French Le nouveau Testament... onto the market. ${ }^{84}$ In the preliminary material, we find a calendar of saints. As regards the text of the New Testament, she used the same text that her Antwerp colleague Johann Gymnich had published a year before. According to Bettye Chambers, it basically offers Jacques Lefèvre's version of the New Testament, but is clearly revised on the basis of the version printed by Pierre de Wingle in Neuchâtel in 1534—a "Protestantizing version" possibly edited by Pierre-Robert Olivetan — and also contains elements of the Vulgate version made by Nicolas de Leuze that was included in the 1550 French Louvain Bible. ${ }^{85}$ In any case, 
the text of the series of delicate, confessionally tinted passages is recognizably catholicized. Apart from Matthew 16:18: "tu es Pierre. Et sus ceste pierre, ie edifierai mon eglise," we read in Matthew 3:2 and Matthew 4:17 "Faictes penitence," in Romans 3:28: "Car nous croyons, que lhome est iustifie par foy sans les oeuures de la loy," and in James 5:14 "Y a il aucun dentre vous malade, quil appelle les prestres de leglise, et quilz prient pour luy" (There are no summaries included above the chapters). The edition concludes with a table indicating the Epistle and Gospel readings for each Sunday and feast day together with the most important saints' days. Maria Ancxt republished this version in $1561 .{ }^{86}$ In this new edition the text of the lessons taken from the Old Testament was actually added (just before the aforementioned table giving the Epistle and Gospel readings that were read at mass). And whereas Gymnich's 1552 New Testament was eventually included in the Index of 1570 , this was not the case with Maria Ancxt's editions.

Aside from at least two complete editions of the French New Testament, Maria Ancxt also published in the period under consideration (more specifically in 1555) a French version of the Euangiles \& Epistres..., the Epistles and Gospels read at mass. Consultation of the only copy that is known to be preserved — and is kept in the New York Public Library— ${ }^{87}$ shows that the text of Matthew 16:13-19, for the feast of the Chair of Saint Peter ("Le jour de la chaire S. Pierre") and that of Saints Peter and Paul has the Vulgate reading "tu es Pierre, et sur ceste pierre iedefieray mon eglise." And just like in the Dutch editions of the Epistles and Gospels, the preliminary material contains, in black and red, a calendar of saints in. In the back of the copy, a table or schedule is added which indicates for all the Sundays and feast days, as well for each and every day of Lenten fast, the respective pages where the liturgical lessons are to be found. ${ }^{88}$ 
I think that only one conclusion can be drawn at the end of this section, namely that the position Christman defended, viz. that Maria Ancxt, in the wake of her husband Jacob van Liesvelt's death, published Reformation-minded biblical material, without the consent of the competent book censors, and in open defiance of the royal edicts, but without being worried by the authorities, cannot be maintained. Close examination of the biblical copies themselves clearly demonstrates that Ancxt brought Catholic or largely catholicized material onto the market, and that the editions, without exception, bear the consent of the competent authorities. Ancxt conformed herself largely to the requirements of the censorship measures, but tried to be as innovative and creative as possible within the boundaries of what was possible, as is shown most clearly by her publication of Campensis's Psalms or the inclusion of Mark 16:15$16 a$ on the title page. In this regard, It should be stressed that during the period concerned, the Catholic authorities in the Low Countries, be them civil or ecclesiastical, had not issued any all-encompassing prohibitions on Bible translations or Bible reading — as Christman suggested they had-but continued to tolerate Catholic vernacular versions. Since Ancxt herself largely conformed with the prevailing regulations, there was simply no need for a (supposed) "pragmatic" toleration of her by the Antwerp city magistrate. This of course does not detract from her merits as a widow of a beheaded printer, for having courageously continued the family business in unfortunate times, as Christman has, with good reason, emphasized in her publications.

\section{THE ENDURING SEDUCTION OF CONFESSIONALLY OR IDEOLOGICALLY INSPIRED DEDUCTIONS IN HISTORY WRITING}

The brash statement that the marginal glosses in Jacob van Liesvelt's 1542 Bible, especially the note that "man's salvation was brought about by Christ alone," were the direct cause of 
the printer's dramatic beheading, continues to pop up in semi-scholarly publications, ditto interviews and exhibition catalogues, not hindered by any critical qualification of Jacob van Wesenbeke's note that lies at the source of the statement. The story or myth regarding the Van Liesvelt family has even been taken to new heights owing to the recent statement—unfounded I argued—made in publications by Victoria Christman, which claims that his widow Maria Ancxt continued her husband's Protestant Bible printing in contravention of the severe censorship measures issued by Habsburg authorities, and without being troubled by the Antwerp town magistrate. Both elements of the Van Liesvelt family story or myth are manifestations of a broader "paradigm," or "Grand Narrative," that continues to underpin the viewpoints of scholars who are not informed by rigid scholarship, and even let themselves be dictated by old-fashioned Protestant or liberal biases. In recent literature, this "paradigm" has been particularly defined as including the idea that the medieval Catholic Church authorities forbade the laity from reading vernacular Bibles and that the Bible was only opened to the masses following the arrival of Protestant Reformers on the scene; a statement that, at least in part, can be traced back to Martin Luther himself. I would like to take the "paradigm" further still, to encompass the related generalisation that, after the advent of the Reformation, the Catholic authorities, both ecclesiastical and civil, intensified their efforts to keep the vernacular Bible out of the hands of the laity. My definition builds upon the analyses offered by scholars such as Andrew Gow ${ }^{89}$ and Sabrina Corbellini (including her Groningen research group),${ }^{90}$ whereas the existence of such an underlying "paradigm" is also recognized in publications written by Kenneth G. Appold ${ }^{91}$ and Peter Marshall. ${ }^{92}$ The "paradigm," and the various myths surrounding it, typically contributed to the construction of the Protestant identity beginning in the Early Modern Era, an identity that was reinforced in the second confessional age between the 1850s and the 1970s, and that unfortunately continues to hold firm in the minds of scholars today when looking at the materials before them. There should 
be no doubt that (some) Catholic scholars also had, and even continue to have, certain prejudices and underlying paradigms in their views on the Reformation Era, but these are less pertinent in the context of the present essay.

* Special thanks are due to Eliza Halling for carefully checking the English of this text and to two anonymous reviewers for their comments upon an earlier version of this essay.

${ }^{1}$ On the occasion of the 500th anniversary of the Reformation, several books were published which focused upon the myths that were created about this ground-breaking event in Church history. Much debated were the works of the American sociologist of religion Rodney Stark, among which was his Reformation Myths: Five Centuries of Misconceptions and (Some) Misfortunes (London: Society for Promoting Christian Knowledge, 2017); Id., Bearing False Witness: Debunking Centuries of Anti-Catholic History (West Conshohocken, PA: Templeton, 2016). See also Peter Marshall, 1517: Martin Luther and the Invention of the Reformation (Oxford: Oxford University Press, 2017) and Peter Opitz, ed., The Myth of the Reformation, Refo500 Academic Studies 9 (Göttingen: Vandenhoeck \& Ruprecht, 2013), among other works.

${ }^{2}$ Recent publications on Van Liesvelt and his Bible production include: August den Hollander, "De Liesveltbijbel van 1526 en later: naar een protestantse bijbel," in De Bijbel in de Lage Landen: Elf eeuwen van vertalen, ed. Paul Gillaerts et al. (Heerenveen: Jongbloed, 2015), 226-236; Wim François, "Jacob van Liesvelt as a Martyr for the Evangelical Belief?," in More than a Memory: The Discourse of Martyrdom and the Construction of Christian Identity in the History of Christianity, ed. Johan Leemans and Jürgen Mettepenningen, Annua Nuntia Lovaniensia 51 (Leuven: Peeters, 2005), 341-369. For concise biographical information on Jacob van Liesvelt, see Anne Rouzet et al., Dictionnaire des imprimeurs, libraires et éditeurs des XVe et XVIe siècles dans les limites géographiques de la Belgique actuelle, Collection du Centre national de l'archéologie et de l'histoire du livre 3 (Nieuwkoop: De Graaf, 1975), 128-129; Paul Bergmans, "Liesvelt (Jacques van)," Biographie Nationale 12 (1892-1893): 121-124.

${ }^{3}$ An overview of Van Liesvelt's Bible editions in A.A. den Hollander, De Nederlandse bijbelvertalingen. Dutch Translations of the Bible 1522-1545, Bibliotheca Bibliographica Neerlandica 33 (Nieuwkoop: de Graaf, 1997). See also the online bibliography of Bibles printed in Belgium and the Netherlands: www.bibliasacra.nl. 
${ }^{4}$ Antwerpsch Archievenblad, ed. Pieter Génard (Antwerp: stadsbestuur, s.d. [1871]), 7:428: "Item gegeven den scerprechtere vanden bibels ende andere boecken van Jacoppe van Liesvelt, boeckprentere, te verbrandene mitten houte ende stroo daartoe gedaen... XXII s. VI d."

${ }^{5}$ See in this regard François, "Jacob van Liesvelt, Martyr," 351-354.

${ }^{6}$ Antwerpsch Archievenblad, ed. Pieter Génard (Antwerp: stadsbestuur, s.d. [1872]), 8:346353.

${ }^{7}$ Recueil des ordonnances des Pays-Bas. Deuxième série:1506-1700, ed. Charles Laurent, Jules Lameere, and Henri Simont, vol. 5, Contenant les ordonnances du 29 janvier 1519 au 31 décembre 1529, ed. Jules Lameere and Henri Simont (Brussels: Goemaere, 1910), 112114. For a discussion of the place of this edict within the broader Bible policy, see Wim François, "Vernacular Bible Reading and Censorship in Early Sixteenth Century. The Position of the Louvain Theologians," in Lay Bibles in Europe. 1450-1800, ed. A.A. den Hollander and Mathijs Lamberigts, Bibliotheca Ephemeridum Theologicarum Lovaniensium 198 (Leuven: Peeters, 2006), 69-96, esp. 86; Jochen A. Fühner, Die Kirchen- und die antireformatorische Religionspolitik Kaiser Karls V. in den siebzehn Provinzen der Niederlande 1515-1555, Brill's Series in Church History 23 (Leiden: Brill, 2004), 298-301. ${ }^{8}$ Antwerpsch Archievenblad, ed. Génard, 8:347: “declaravit reus dat de boecken byden aenleggere gespecificeert, langhen tydt voer de placcaten Ons Genadichs Heeren des Keysers ende vele jaeren te voren, by diverse boeckprinters, gedruckt hebben geweest ende mids datse by gheenen mandaten en syn verboden geweest, ende dat meer is, dat eenighe van dien syn gedruckt cum gratia et privilegio, dat hy vuyt dien (nyet meynende ydt daerane te misdoene) deselve alleenlick naegedruckt heeft voer date vanden lesten mandemente."

${ }^{9}$ Floris Prims, Geschiedenis van Antwerpen, vol. 7, Onder de eerste Habsburgers (14771555). 1, De politische orde (Antwerp: Standaard Boekhandel, 1938), 129. Prims's hypothesis, however, is corroborated by the similar case of the printer Adriaen van Berghen. In 1542, a lot of heterodox books were seized from his printing shop in Delft, Holland, but he only received a light punishment from the judge in his local town. The Attorney General from the Court of Holland was however unsatisfied with this light sentence, and sent Van Berghen to The Hague, where the trial was redone. It was concluded with Van Berghen being sentenced to death by beheading. See, for this case, Maria Elizabeth Kronenberg, Verboden boeken en opstandige drukkers in de Hervormingstijd, Patria Vaderlandse cultuurgeschiedenis in monografieën 44 (Amsterdam: P.N. Van Kampen \& zoon N.V., 1948), 92.

${ }^{10}$ Antwerpsch Archievenblad, ed. Génard, 8:353. 
${ }^{11}$ The Antwerpsch Chronykje, in which it was common to jot down the executions, does not mention Jacob van Liesvelt's. Moreover, it is not mentioned in the sheriff's bills. These are reasons for Prims to assume that the Court of Brabant had taken over this case (Prims, Geschiedenis van Antwerpen, 7/1:128-129).

${ }^{12}$ Cebus Cornelis de Bruin, De Statenbijbel en zijn voorgangers. Nederlandse bijbelvertalingen vanaf de Reformatie tot 1637, rev. Frits Gerrit Murk Broeyer (Haarlem: Nederlands Bijbelgenootschap and Brussels: Belgisch Bijbelgenootschap, 1993), 151-152. ${ }^{13}$ [Jacques de Wesenbeke,] De beschriivinge van den gheschiedenissen in der religien saken toeghedragen in den Nederlanden... ([Cologne: Gottfried Hirtshorn], 1559 [=1569]), 22: "Jacop van Liesvelt tAntwerpen om eenen Bijbel in Nederduytsch na ghedruct te hebben met een Marginale Annotatie dat des Menschen salicheyt alleen doer Christum quam"; Jacques van Wesenbeeck, La description de l'estat succes et occurences, advenues au Pais bas au faict de la Religion ([Cologne: Gottfried Cervicornus d.J.], 1569), 20: "Jacques Van Liesvelt en Anvers, pour avoir après ung autre exemplaire imprimé une Bible avec une marginale annotation, que la salvation de l'homme procédoit seullement par Jesu-Christ" (the text has been published in Jacques de Wesenbeke, Mémoires de Jacques de Wesenbeke, intr. and notes Charles Rahlenbeck, Collection de mémoires relatifs à l'histoire de Belgique 5 [Brussels: Weissenbruch, 1859], 47-392, here 68; in this article I refer to Rahlenbeck's nineteenth century French edition of Van Wesenbeke's work).

${ }^{14}$ Elementary biographical information is to be found in: Petrus Johannes Blok, "Wesembeke, Wesembeecke, Wesembeek (Jacob van)," Nieuw Nederlandsch Biografisch Woordenboek 5 (1921): 1112-1115; Herman Vander Linden, “Wesenbeke (Jacques van)," Biographie Nationale de Belgique 27 (1938): 206-211; Robert Van Roosbroeck, "Wesembeke (Wesenbeke), Jakob van,” Nationaal Biografisch Woordenboek 5 (1972): 997-1003.

15 This involves a nuance in comparison to François, “Jacob van Liesvelt, Martyr,” 354.

${ }^{16}$ De Wesenbeke, Mémoires, ed. Rahlenbeck, 252-253.

${ }^{17}$ On Van Wesenbeke as ghostwriter and minister of propaganda in the service of William of Orange, see in particular Pieter Antoon Marie Geurts, De Nederlandse Opstand in de Pamfletten 1566-1584 (Nijmegen: Dekker \& Van de Vegt, 1956; repr. Utrecht: Hes, 1978); also: Martin Van Gelderen, The Political Thought of the Dutch Revolt 1555-1590, Ideas in Context, 2nd ed. (Cambridge: Cambridge University Press), 2002, 115-119; Gustaaf Asaert, Met Jacob van Wesenbeke naar Spanje. Een diplomatieke reis in een bewogen tijd (15621563) (Antwerp: Antwerpse Vereniging voor Bouwhistorie en Geschiedenis, 2017).

${ }^{18}$ Geurts, De Nederlandse Opstand, 27-28, 32-33. 
${ }^{19}$ De Wesenbeke, Mémoires, ed. Rahlenbeck, 52: “plusieurs (ausquelz ne vouldrois refuser chose que seroit en ma puissance) m'en ont requis."

${ }^{20}$ Geurts, De Nederlandse Opstand, 33.

${ }^{21}$ But the wish of the author, which he has expressed in the introduction of his book, namely to also offer a translation in Latin and in German, has never been fulfilled; neither was his aim to also publish a second and even third part to the work in four languages (De Wesenbeke, Mémoires, ed. Rahlenbeck, 49-50). William of Orange, for his part, did efforts to realize the publication of two parts in German (Geurts, De Nederlandse Opstand, 33-34; cf. Jan Frederik van Someren, "Wesenbeke of Marnix?," Oud-Holland 10, no 2 [1892]: 66-75, esp. 67-68). ${ }^{22}$ Rahlenbeck includes a footnote where he refers to M. Ebhardt, President to the Court of Appeal in Dillenburg, who provided him with the following information: "En 1576 ... la ville d'Anvers s'adressa à l'un des réfugiés flamands de Dillenbourg—son nom est illisible_pour savoir ce qu'étaient devenus les sceaux de la commune, les papiers et les lettres que Jacques de Wesenbeke avaient pris avec lui” (De Wesenbeke, Mémoires, ed. Rahlenbeck, XIII n. 1). ${ }^{23}$ Not all of Van Wesenbeke's projects saw immediate success, which caused irritation with the Prince of Orange, in particular when it was believed that this was due to Van Wesenbeke's obstinacy and self-will. Two weeks after the capture of Den Briel, Van Wesenbeke published the proclamation of April 14, 1572, which was addressed to the people of the Low Countries, and he did so without beforehand communicating the content of the proclamation to the Prince. William of Orange's dissatisfaction over this incident eventually led to Van Wesenbeke being brushed aside, and his role as minister of propaganda of the Revolt being taken over by Marnix of Saint-Aldegonde. See Geurts, De Nederlandse Opstand, 40-42, 4647.

${ }^{24}$ Col. 1:2: "genade dats vergevinge der sonden door Cristum, vrede dat is dat in ons te weten is dat wi seker gheloven door Cristum salich te zijn."

${ }^{25}$ Matt. 4:23: "Euangelie, dat is de vercondinghe der gratien ende verlossinge gecregen ende gegeuen door cristum ende lange verwacht."

${ }^{26}$ Rom. 10: "dye rechtveerdicheyt welcke waerdich maect totten eewighen leven alleen is bi die wet ende tgeloove Jesu Christi."

${ }^{27}$ Den Bybel [...] (Antwerp: Jacob van Liesvelt, 1542), vv: "Die gracie Jesu cristi maect ons salich ende niet die wercken."

${ }^{28}$ Isaac Le Long, Boek-Zaal der Nederduytsche Bybels... (Amsterdam: Hendrik Vieroot, 1732), $567-569$. 
${ }^{29}$ Le Long, Boek-Zaal, 568-569: "tot weinig Jaaren voor dat de Nieuwe Gereformeerde Oversettinge in 't licht is gekomen" [my translation].

${ }^{30}$ Le Long, Boek-Zaal, 567-568: “geduurende de hevigste vervolginge tegens de Voorstanders van Gods-Woordt ... Mr. Jacob van Wesenbeek, Raadt en Pensionaris der Stadt Antwerpen, die het selve beleeft ... heeft" [my translation].

${ }^{31}$ Le Long, Boek-Zaal, 568-569: “de Regulier Nicolaes van Winge, daar van dese gewaande reeden geeft: 'Om dat de Valsche Bybelen soude te niet gedaan worden, en niet, om dat men geen Heylige Schriftuer in Gemeynder Taelen soude mogen leesen...' Dat dit onbeschaamde Leugens en Lasteringen zyn, hebben wy meermaals in dit Werk gesegt, ook in 't breede beweesen; en 't blykt nog heedendaags by de Stukken; vermits niet de Gereformeerden, maar de Roomschgesinde de Bybel vervalscht, en in de gemeene Taale te lesen verbooden hebben" [my translation].

32 Albert van Toorenenbergen, Schetsen uit de lijdensgeschiedenis der Protestantsche Apostolisch-Katholieke Kerk (Amsterdam: C.L. Brinkman, 1854), 1:84-89.

${ }^{33}$ Van Toorenenbergen, Schetsen uit de lijdensgeschiedenis, 89: "Nauwelijks was de laatste uitgave in 1542 voltooid, waar Liesveldt onderscheidene kanttekeningen had bijgevoegd ... maar vooral, nauwelijks had de geestelijkheid gelezen, dat 'de saelicheyt der menschen alleen compt door Jesum Christum' of het lot des uitgevers was beslist."

${ }^{34}$ Van Toorenenbergen, Schetsen uit de lijdensgeschiedenis, 84-85: “Al vinden we zijnen naam niet in de martelaarsboeken, toch mag zijn sterven door ons hier niet vergeten worden ... [hij heeft] voor den Bijbel alles opgeofferd ... [hij is] om den Bijbel gestorven, die hij zelf bewerkt, gedrukt, uitgegeven en bloedig bezegeld heeft" [my translation].

${ }^{35}$ Frans Hendrik Mertens and Karel Lodewyk Torfs, Geschiedenis van Antwerpen sedert de stichting der stad tot onze tyden (Antwerp: Drukkery van J.-E. Buschmann,1848), 4:275-276:

"Dit laatste werd als een onvergeeflyk schelmstuk aengemerkt; weshalve de drukker en uitgever van den Liesveldtschen Bybel in 1545 te Antwerpen openbaerlyk werd onthoofd." ${ }^{36}$ Mertens and Torfs, Geschiedenis van Antwerpen, 4:275: "zy verdedigden de vryheid der drukpers, welke men toen al bedacht was aen banden te leggen."

${ }^{37}$ Hendrik van Druten, Geschiedenis der Nederlandsche Bijbelvertaling, tweede deel. Eerste stuk (Rotterdam: D.A. Daamen, 1897), 428-430.

${ }^{38}$ Van Druten, Geschiedenis der Nederlandsche Bijbelvertaling, 429-430.

${ }^{39}$ Van Druten, Geschiedenis der Nederlandsche Bijbelvertaling, 428: "Niet om zijn tekst maar vooral om de aanteekeningen was deze editie vogelvrij verklaard en de drukker zelf des doods schuldig bevonden" [my translation]. 
${ }^{40}$ Jan Frederik Beerens, De herkomst van den Bijbel (Zeist: G.J.A. Ruys' Uitg.-Mij, 1925), $113-114$.

${ }^{41}$ Beerens, De herkomst van den Bijbel, 114: "Bovendien waren zijn houtsneegravuren zeer prikkelend ... Dit alles was de geestelijkheid een doorn in 't oog. Daarom heeft zij niet gerust voor de uitgever tot den vuurdood was veroordeeld. Doch daarom juist stond zijne uitgave bij de Protestanten in hooge achting. Zij was door martelaarsbloed gewijd" [my translation]. ${ }^{42}$ Prims, Geschiedenis van Antwerpen, 7/1:128-129; but also vol. 7/3, Geestelijke orde (Antwerp: Standaard Boekhandel, 1940), 291, 294-296.

${ }^{43}$ Prims, Geschiedenis van Antwerpen, 7/1:128: "Het ging dus niet alleen, noch bijzonderlijk, om den Bijbel van 1542 zooals overal is te lezen."

${ }^{44}$ Prims, Geschiedenis van Antwerpen, 7/1:128; cf. 7/3:296: "Jacob van Wesenbeke teekende op dat Liesvelt veroordeeld werd om een marginale nota 'dat de zaligheid der menschen alleenlijk van Jezus-Christus komt'. Het is een tendentieuse en wel-onvolledige voorstelling." ${ }^{45}$ Cebus Cornelis de Bruin, De Statenbijbel en zijn voorgangers (Leiden: A.W. Sijthoff's Uitgeversmij, 1937), 165-169, 211-212. In the adaptation of this basic work of De Bruin, which has been provided by Frits G.M. Broeyer and has been released in 1993, the section on Jacob van Liesvelt has not been changed in content (de Bruin, De Statenbijbel en zijn voorgangers, rev. Broeyer, 102-103).

${ }^{46}$ De Bruin, De Statenbijbel en zijn voorgangers, 211-212: "Whatever the exiles had to leave behind in their home country, one thing they did take while dispersed was their Bible. It is not doubtful which edition was most loved among them. It had been the Liesvelt Bible, in which they found comfort and refreshment in those years... During those years, the Liesvelt Bible had served among the emigrants of the diverse religious denominations that distinguished themselves gradually, as well as among Anabaptists and the Reformed, as among the small group of Lutherans. Despite all their differences in religious thinking, the Dutch Protestants kept on honoring the Liesvelt Bible that had indeed been drenched with blood and tears" ("Wat de ballingen in het moederland ook moesten achterlaten, één ding namen zij in de verstrooiing met zich mede: hun bijbel. Het is niet twijfelachtig, welke uitgave onder hen het meest geliefd was. De Liesveldtbijbel is het geweest, waaruit zij in deze jaren troost en verkwikking geput hebben... In deze jaren heeft de Liesveldtbijbel dienst gedaan bij de uitgewekenen van de godsdienstige richtingen, die zich allengs gingen onderscheiden, zoowel dus bij Doopsgezinden en Gereformeerden als bij het groepje Lutherschen. Ondanks alle verschillen in religieuze denkwijze hebben de Nederlandsche Protestanten den Liesveldtbijbel, die immers met zooveel bloed en tranen gedrenkt was, in eere gehouden" [my translation]). 
${ }^{47}$ De Bruin, De Statenbijbel en zijn voorgangers, 168.

${ }^{48}$ De Bruin, De Statenbijbel en zijn voorgangers, 168-169.

${ }^{49}$ De Bruin, De Statenbijbel en zijn voorgangers, 199-210.

${ }^{50}$ De Bruin, De Statenbijbel en zijn voorgangers, 169: "Er is reden om de vraag te stellen of Jacob van Liesveldt terecht te beschouwen is als martelaar" [my translation].

${ }^{51}$ De Bruin, De Statenbijbel en zijn voorgangers, 169.

52 De Bruin, De Statenbijbel en zijn voorgangers, 169: “Zoo herdenken wij met eerbied den dapperen Antwerpschen uitgever, die eigen leven niet achtend, door zijn bijbels talloos velen ten zegen is geweest" [my translation].

53 Kronenberg, Verboden boeken en opstandige drukkers, 135-136. See n. 9 for the full reference.

${ }^{54}$ Kronenberg, Verboden boeken en opstandige drukkers, 135: "Het drukken van de z.g. Liesveltse Bijbel van 1542, bij de Protestanten in hoog aanzien gebleven, de aanleiding tot zijn doodvonnis is geweest" [my translation].

${ }^{55}$ Kronenberg, Verboden boeken en opstandige drukkers, 136: "Men zoekt hun aller namen tevergeefs bij Van Haemstede in zijn werk over de Nederlandse martelaren. Een plaats daarin hadden ze echter ten volle verdiend" [my translation].

${ }^{56}$ De Bruin, De Statenbijbel en zijn voorgangers, rev. Broeyer, 94-103, 151-152.

${ }^{57}$ Den Hollander, Nederlandse Bijbelvertalingen 1522-1545, 513.

${ }^{58}$ Den Hollander, Nederlandse Bijbelvertalingen 1522-1545, 28-36.

${ }^{59}$ Den Hollander also devoted a Dutch article to Van Liesvelt and his Bibles: "Dat Oude ende dat Nieuwe Testament (1526): Jacob van Liesvelt en de nieuwe markt voor Bijbels in de zestiende eeuw," Jaarboek voor Nederlandse Boekgeschiedenis 6 (1999): 105-122. In this article, the author considers Van Liesvelt in a more "traditional" framework, thus accepting that Van Liesvelt had been executed because of his 1542 Bible and the Reformation-minded glosses it included (pp. 108 and 120). Moreover, Den Hollander describes-with due sympathy-that Van Liesvelt's Bible continued to be used among those sympathetic to the Protestant Reformation after the printer's execution and that it went through several reprints and revisions, and was even edited up until the first half of the seventeenth century. The author recognizes that the Liesvelt-Bible could and also can be the symbol of the thoroughly Bible-based Dutch Protestantism in this period (see the conclusion, p. 121). ${ }^{60}$ August den Hollander, “De Liesveltbijbel van 1526 en later,” 226-236. 
${ }^{61}$ Victoria Christman, Pragmatic Toleration: The Politics of Religious Heterodoxy in Early Reformation Antwerp, 1515-1555, Changing Perspectives on Early Modern Europe 17 (Rochester, NY: University of Rochester Press, 2015), esp. 80-82.

${ }^{62}$ Victoria Christman, "The Coverture of Widowhood: Heterodox Female publishers in Antwerp, 1530-1580," The Sixteenth Century Journal 42, no. 1 (Spring 2011): 77-97, esp. 77-78, 84-85, and esp. 86-89.

${ }^{63}$ On Maria Ancxt see Heleen Wyffels, "Weduwen-drukkers in 16de eeuws Antwerpen. Samengebracht in een biobibliografisch repertorium," De Gulden Passer 95, no. 2 (2017): 231-260, esp. 239-240; Rouzet et al., Dictionnaire des imprimeurs, 129-130.

${ }^{64}$ On Bible censorship culminating with the Louvain Index, see Wim François, "De Leuvense Bijbel (1548) en de katholieke bijbelvertalingen van de tweede helft van de zestiende eeuw," in De Bijbel in de Lage Landen, ed. Gillaerts et al., 266-303, esp. 270-273; François, "Vernacular Bible Reading and Censorship," 79-91; August den Hollander, Verboden bijbels: Bijbelcensuur in de Nederlanden in de eerste helft van de zestiende eeuw, Oratiereeks (Amsterdam: Vossiuspers UvA, 2003), 6-21. On the Louvain Index, see also Jesús Martínez De Bujanda et al., Index de l'Université de Louvain, 1546, 1550, 1558, Index des livres interdits 2 (Sherbrooke: Université de Sherbrooke. Centre d'études de la Renaissance and Geneva: Droz, 1986), esp. 46, 65-68, 106-130, 408-412.

${ }^{65}$ Regarding the Dutch Louvain Bible, see especially François, "De Leuvense Bijbel (1548) en de katholieke bijbelvertalingen," 276-294; Pacificus Van Herreweghen, "De Leuvense bijbelvertaler Nicolaus van Winghe. Zijn leven en zijn werk," Ons Geestelijk Erf 23 (1949): 5-38, 150-167, 268-314, and 357-395. See also: Jean-François Gilmont, "La concurrence entre deux Bibles flamandes," in Id., Le livre et ses secrèts, Cahiers d'humanisme et renaissance 65; Temps et espaces 2 (Geneva: Droz and Louvain-la-Neuve: UCL. Bibliothèque de la Faculté de philosophie et lettres, 2003), 151-162, esp. 152-155; de Bruin, De Statenbijbel en zijn voorgangers, rev. Broeyer, 141-147. On the French Louvain Bible see, amongst others, Pierre-Maurice Bogaert and Jean-François Gilmont, "La première Bible française de Louvain (1550)," Revue Théologique de Louvain 11, no. 3 (1980): 275-309; Id., "De Lefèvre d'Étaples à la fin du XVIe siècle," in Les Bibles en français: Histoire illustrée du Moyen Âge à nos jours, ed. Pierre-Maurice Bogaert (Turnhout: Brepols, 1991), 47-106, esp. 89-91.

${ }^{66}$ Christman, Pragmatic Toleration, 81-82; "the Coverture of Widowhood," 84-85.

${ }^{67}$ Jesús Martínez De Bujanda et al., Index de Rome 1557, 1559, 1564: Les premiers index romains et l'index du Concile de Trente, Index des livres interdits 8 (Sherbrooke: Université 
de Sherbrooke. Centre d'études de la Renaissance and Geneva: Droz, 1990), 37-39, 128-131, 137, 307-331, esp. 325, 331. Also Giorgio Caravale, Forbidden Prayer: Church Censorship and Devotional Literature in Renaissance Italy, trans. Peter Dawson (Farnham: Ashgate, 2011), 71-73 and W. François, "The Catholic Church and the Vernacular Bible in the Low Countries: A Paradigm Shift in the 1550s?," in Discovering the Riches of the Word: Religious Reading in Late Medieval and Early Modern Europe, ed. Sabrina Corbellini, Margriet Hoogvliet, and Bart Ramakers, Intersections 38 (Leiden: Brill, 2015), 234-281, esp. 262-263. ${ }^{68}$ Christman, Pragmatic Toleration, 82; "the Coverture of Widowhood," 88: Christman only mentions "more than a half dozen vernacular Bible translations."

${ }^{69}$ We consulted for 1547.EpEv.dut.MA.a: Leuven, University Library, R 3A 12023; for 1548.EpEv.dut.MA.a: Stuttgart, Württembergische Landesbibliothek, B niederländ. 154801 [The codes given to the editions are borrowed from and, if necessary, adapted on the basis of the aforementioned database www.bibliasacra.nl].

70 "Ende ic segge u ooc, ghi sijt Petrus, ende op desen steen sal ic timmeren mijn kercke."

${ }^{71}$ Three editions are known to have been published during the course of 1532, first by Johann Petreius (Nürnberg), and then by Merten de Keyser (Antwerp) and Claude Chevallon (Paris).

${ }^{72}$ Henry de Vocht, History of the Foundation and the Rise of the Collegium Trilingue Lovaniense 1517-1550, 4 vols. (Leuven: Librairie universitaire, 1951-1955), 2:120-122 and 3:154-208, esp. 190-195; Id., "Campensis' Psalterium," in Id., John Dantiscus and His Netherlandish Friends, As Revealed by Their Correspondence 1522-1546, Humanistica Lovaniensia 16 (Leuven: Librairie universitaire, 1961), 136-148; Jamie H. Ferguson, "Miles Coverdale and the Claims of Paraphrase," in Psalms in the Early Modern World, ed. Linda Phyllis Austin et al. (Farnham: Asghate, 2011), 137-154.

${ }^{73}$ De Bujanda et al., Index de Rome 1557, 1559, 1564, 79: Campensis's works have been included in the severe Roman Index of 1559. The commission in Trent, charged with the revision of the Index, declared to have erased from the draft list the names of Catholic authors who are among the heretics, among whom was Johannes Campensis. Campensis was nevertheless included, with all his works, in the Tridentine Index of 1564.

${ }^{74}$ We consulted for 1548.Ps.dut.MA.a: Brussels, Royal Library, II 53.131 A and Ghent, University Library, Theol. 2790; for 1548.Ps.dut.MA.b: Ghent, University Library, Acc. 776; and for 1548.Ps.dut.MA.c: Liège, Bibliotèque du Séminaire, 23.T.23.

${ }^{75}$ We consulted for 1549.Ps.dut.MA.a: Antwerp, Hendrik Conscience Heritage Library, F 41386 [C2-pdm $1 \mathrm{f}]$. 
${ }^{76}$ We consulted for 1553.NT.dut.MA.a: Brussels, Royal Library, LP 3098 A; for 1555.NT.dut.MA.a: Amsterdam, Library UvA, OTM: OK 62-5551; for 1557.NT.dut.MA.a: Westerlo, Premonstratensians' Abbey; for 1560.NT.dut.MA.a: Antwerp, Hendrik Conscience Heritage Library, F 78342 (C2-553 g); for 1561.NT.dut.MA.a: Amsterdam, Library UvA, OK 63-1128, and Amsterdam, Library VU, XC.06705; for 1562.NT.dut.MA.a: Brussels, Royal Library, CAP 184 A (RP) (= Olim Antwerp, Archief van de Vlaams-Belgische Provincie der Kapucijnen); and for 1565.NT.dut.MA.a: London, British Library 3041.aaa.18.

${ }^{77}$ François, "Catholic Church and the Vernacular Bible in the Low Countries," 265-275.

${ }^{78}$ Den Hollander, Verboden Bijbels, 21.

${ }^{79}$ Summary above Matt. 16, according to Liesvelt's New Testament (1540) (comp. Liesvelt Bible [1535]): "Van die leeringhe der Pharizeen, Hoe Jesus sprac, dat hi zijn kercke tymmeren soude op die belijdinge des gheloofs. Hoe Petrus nae sijn belijdinghe van Christus ghestraft wert, Ende dat een yeghelijck zijn cruys draghen moet, die Christum na volghen wil, Ende dat sommige die doot niet sien en sullen voor dat si den sone des menschen in sijn rijcke sien" [emphases in bold are mine].

${ }^{80}$ Summary above Matt. 16, according to Ancxt's New Testament (1553): "Van die leeringhe der Phariseen. Hoe Jesus sprack, waer op dat hy zijn kercke tymmeren soude [xxx]. Hoe Petrus na zijn belijdinghe van Cristus ghestraft werdt. Ende dat een yeghelijck zijn cruys dragen moet, die Christum na volghen wilt, ende dat God een yegelijc doen sal naer zijn gewercken" [emphases in bold are mine].

${ }^{81}$ Summary above Matt. 16, according to the 1553 Louvain Bible: "Hoe Jesus die Phariseen een teeken begherende berispt. Ende hoe hy ondervraecht zijn discipelen wie dat die menschen seggen dat hi is. Ende hoe hi Peeter beloeft die slotelen des hemelrijcx. Hoe hi zijn lijden te kennen gheeft ende leert dat ieghelijc met zijn cruys hem naevolghen sal."

82 1560.B.dut.MA.a et 1560.B.dut.MA.b. We have consulted Leuven, Maurits Sabbe Library, P 22.055.1/F $\mathrm{F}^{\circ} \mathrm{BIJB} 1560$.

${ }^{83}$ 1560.B.dut.MA.c. We have consulted Leuven, Maurits Sabbe Library, P 22.055.1/F $\mathrm{F}^{\circ}$ BIJB 1560.

${ }^{84}$ We consulted for 1553.NT.fre.MA.a: Munich, University Library, $8^{\circ}$ Bibl. 1175.

${ }^{85}$ Bettye Chambers, Bibliography of French Bibles, vol. 1, Fifteenth-and Sixteenth-Century

French-Language Editions of the Scriptures, Travaux d'humanisme et renaissance 192

(Geneva: Droz, 1983), 202-203, also 188.

${ }^{86}$ We consulted for 1561.NT.fre.MA.a: Stuttgart, Württembergische Landesbibliothek, B franz.156101. 
${ }^{87}$ We consulted for 1555.EpEv.fre.MA.a: New York Public Library *KB 1555.

${ }^{88}$ Maria Ancxt also published in her Antwerp printing office Le Psaultier de David. Reduict en forme d'oraysons, contenant. C.L. Psalmes nouvellement traduict de bas alleman en langue Francoyse [par Jean de Fleurs]. It is known that she published two editions, viz. 1553 and 1554. The text is quite removed from the canonical text of the Bible, but offers meditative prayers on the basis of the Psalms. Obviously, it is based upon a (until now unknown) Dutch translation. The text was published with the approval by "un home scavant de LImp. Maieste a ce commis." Complimentary to this work was an Alphabet Chrestien. Extraict du Psaultier de Dauid et aultres lieux de l'Escripture saincte, two editions of which were published by Maria Ancxt, viz. in the same years 1553 and 1554. Also a Dutch version of the latter work has been preserved: Eenen gheestelijcken A.B.C. ghetoghen uut de psalmen van David, published by Ameet Tavernier around 1550. The Dutch text of the (prayers to these) Psalms, upon which Eenen gheestelijcken A.B.C was probably based, is lost. The aforementioned books bear witness to the general practice of that period, namely to teach children reading on the basis of the Psalter. To this should be added that Le Psaultier de David by Maria Ancxt was included in the Index of Antwerp in 1570.

${ }^{89}$ Andrew C. Gow, “The Contested History of a Book: The German Bible of the Later Middle Ages and Reformation in Legend, Ideology, and Scholarship," Journal of Hebrew Scriptures 9 (2009): 2-37; Id., "Challenging the Protestant Paradigm: Bible Reading in Lay and Urban Contexts of the Later Middle Ages," in Scripture and Pluralism. Reading the Bible in the Religiously Plural Worlds of the Middle Ages and the Renaissance, ed. Thomas J. Heffernan and Thomas Burman, Studies in the History of Christian Traditions 123 (Leiden: Brill, 2005), $161-191$.

${ }^{90}$ Sabrina Corbellini et al., "Challenging the Paradigms: Holy Writ and Lay Readers in Late Medieval Europe," Church History and Religious Culture 93, no. 2 (2013): 171-188.

${ }^{91}$ Kenneth G. Appold, "The importance of the Bible for early Lutheran theology," in The New Cambridge History of the Bible, vol. 3, From 1450 to 1750, ed. Euan Cameron (Cambridge: Cambridge University Press, 2016), 439-461, esp. 439: "Statements such as 'Luther rescued the Bible from papal tyranny', 'the Reformation gave the Bible back to the people' or 'the 
Catholic church banned Bible-reading' are among the more popular of the (typically Protestant) generalisations which, at the very least, need heavy qualification."

${ }^{92}$ See especially item 3 of the Oxford University Press blog that Peter Marshall contributed to, in order to commemorate the 500th anniversary of the Reformation and mark the publication of his book Martin Luther and the Invention of the Reformation (See n. 1 for the full reference to the book). For the blog, see: https://blog.oup.com/2017/10/9-mythsreformation/ (Accessed August 9, 2019). 